\title{
Extramedullary plasmacytomas and prognostic implications in multiple myeloma
}

\section{Francisco Gil', Marta Duarte ${ }^{2}$}

\author{
${ }^{1}$ Dermatology Department, Hospital Distrital de Santarém, Santarém, Portugal, ${ }^{2}$ Clinical Hematology Unit, Hospital \\ Distrital de Santarém, Santarém, Portugal
}

Corresponding author: Dr. Francisco Gil, E-mail: franciscosgil@gmail.com

Multiple myeloma is a malignant proliferation of monoclonal plasma cells and is often confined to the bone and bone marrow. When the disease affects organs besides the bone or the bone marrow is called extramedullary plasmacytoma [1].

We describe the case of a 68-year-old male, with an IgG lambda multiple myeloma under secondline therapy with bortezomib, thalidomide and dexamethasone after lack of response to first-line treatment, presenting to dermatology department due to the recent development of an erythematousviolaceous nodule of $1,2 \mathrm{~cm}$ of diameter on the left flank (Fig. 1), an occipital subcutaneous mass with $5 \times 5 \mathrm{~cm}$ (Fig. 2) and 4 subcutaneous nodules on the forehead (Fig. 3), between 1,5 and $2 \mathrm{~cm}$ of diameter. Lesions were asymptomatic and had grown rapidly in size over weeks. Skin biopsy revealed a dermal and subcutaneous nodular proliferation of immature plasma cells, morphologically and immunohistochemically consistent with cutaneous plasmacytoma. Cranial and maxillofacial computed tomographies were requested, revealing

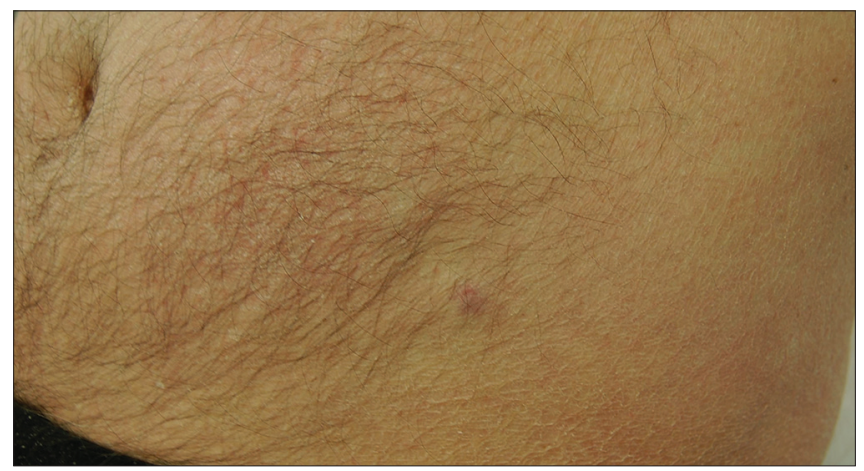

Figure 1 : Erythematous-violaceous nodule on the left flank. spontaneously dense regular masses at the parietal, right paramedian, frontal and right malar regions, with a lytic infiltrative aspect causing irregularity of the cortical bone and diploe (Fig. 4). The patient died 2 months later from extensive and rapid extramedullary progression.

Cutaneous plasmacytomas can occur primarily in the skin, without involvement of the bone marrow, or secondarily, from the dissemination of multiple myeloma or plasma cell leukemia [2]. Secondary cutaneous plasmacytomas occur by direct extension from underlying bone lesions or by hematogenic spread. Typically these lesions present as cutaneous or subcutaneous nodules or masses and can be erythematous-violaceous or normochromic [1,2]. There are frequently multiple lesions, of smooth and raised surface, more commonly on the trunk, extremities and face [2]. These lesions occur late in the course of the disease and dictate a poor prognosis,

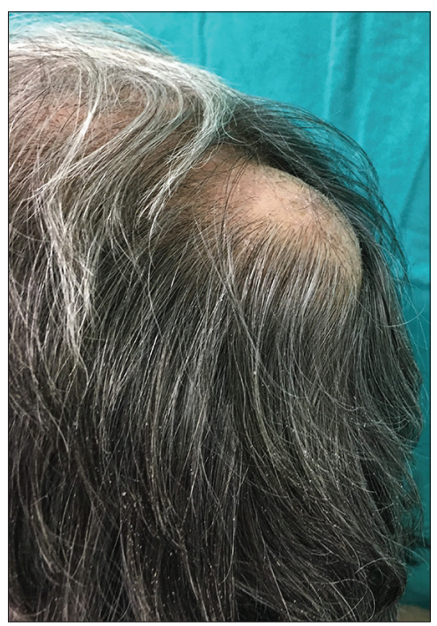

Figure 2: Normochromic subcutaneous mass on the occipital region.

\footnotetext{
How to cite this article: Gil F, Duarte M. Extramedullary plasmacytomas and prognostic implications in multiple myeloma. Our Dermatol Online. 2020;11(1):84-85. Submission: 01.09.2019; Acceptance: 12.11.2019 DOI:10.7241/ourd.20201.23
} 
www.odermatol.com

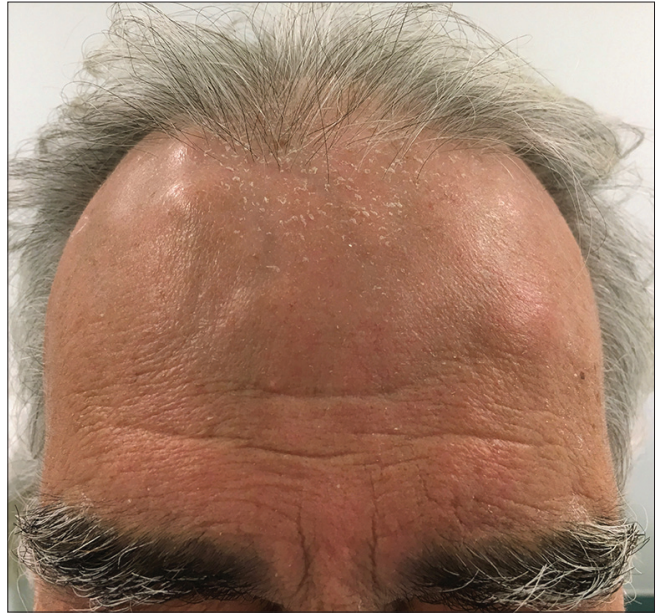

Figure 3 : Frontal subcutaneous nodules.

with $50 \%$ of the patients dying within 6 months after diagnosis $[2,3]$.

\section{Consent}

The examination of the patient was conducted according to the Declaration of Helsinki principles.

\section{REFERENCES}

1. Yoo J, Jo M, Kim M, Jue M, Park H, Choi K. Cutaneous plasmacytoma: metastasis of multiple myeloma at the fracture site.

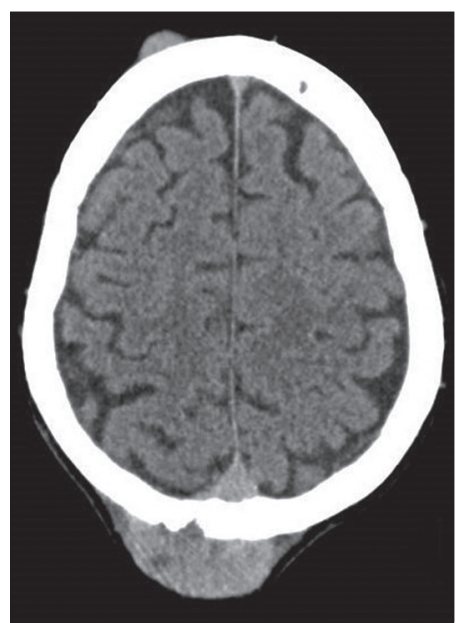

Figure 4: Computed tomographic aspect of the extracranial subcutaneous masses.

Ann Dermatol. 2017;29:483-6.

2. Souza D, Muller H, Freitas T, Hungria V, Paes R. Mieloma múltiplo com plasmocitomas cutâneos. An Bras Dermatol. 2004;79:581-5.

3. Bhatnagar A, Verma R, Bhatia J K, Sood A, Das P. Secondary cutaneous plasmacytoma: A bad prognostic marker. J Appl Hematol. 2015;6:172-4.

Copyright by Francisco Gil, et al. This is an open access article distributed under the terms of the Creative Commons Attribution License, which permits unrestricted use, distribution, and reproduction in any medium, provided the original author and source are credited.

Source of Support: Nil, Conflict of Interest: None declared. 